\title{
Principles of visual evaluation of test results using the emotional component
}

\author{
Yudina A., Chornyi O.*, Serhiienko S. \\ Kremenchuk Mykhailo Ostrohradskyi National University, Kremenchuk, Ukraine
}

Received: $21.03 .2019 \quad$ Accepted: 15.04 .2019

\begin{abstract}
The paper shows that evaluation using a visual image of a face is an alternative to traditional quantification of test results, since a combination of modern learning technologies with visual and emotional impact methods can provide greater efficiency compared to traditional, classical methods. The paper substantiates the possibility of using Chernov's faces in the assessment and the methods for constructing the assessment - the "student's face" based on the values of the multidimensional vector of test results. Methods are provided for the construction of individual assessments of each student and the student group of integrated assessments on the basis of passing the tests of the first level. Also, principles and tools were presented for comparing answers to test questions with facial features and the possibility of displaying them in the form of graphic primitives. The main provisions of the technology of building a visual assessment of test results using the emotional component were formulatedAlso, the article provides an example of building a visual assessment of students using Chernov's facial technique based on a statistical table of test results data.
\end{abstract}

Key words: intellectual visualization, Chernov's face, assessment methods, assessment - smiley.

\section{Принципи візуальної оцінки результатів тестування з використанням емоційної складової}

\author{
Юдіна А. Л., Чорний О. П., Сергієнко С. А. \\ Кременчуцький національний університет імені Михайла Остроградського, Кременчук, Україна
}

\begin{abstract}
Анотація. Показано, що альтернативою традиційному кількісному оцінюванню результатів тестування $€$ оцінювання за допомогою візуального зображення обличчя, оскільки поєднання сучасних технологій навчання з методами візуального і емоційного впливу може забезпечити більшу ефективність у порівнянні 3 традиційними, класичними методами. В роботі обірунтована можливість використання техніки обличь Чернова в оцінюванні та способи побудови оцінки - «обличчя студента» за значеннями багатовимірного вектору результатів тестування, що дозволяє провести оцінювання на інтуїтивному рівні. Представлені способи побудови індивідуальних оцінок кожного студента та інтегрованих оцінок студентської групи на основі результатів проходження тестів першого рівня. Наведені принципи та засоби співставлення відповідей на питання тесту з рисами обличчя та можливість їх відображення у вигляді графічних примітивів. Сформульовані основні положення технології побудови візуальної оцінки результатів тестування 3 використанням емоційної складової. Наведено приклад побудови візуальної оцінки студентів з використанням техніки обличь Чернова на основі статистичної таблиці даних результатів тестування.

Ключові слова: інтелектуальна візуалізація, обличчя Чернова, способи оцінювання, оцінка - смайлик.
\end{abstract}

\footnotetext{
Corresponding Author: Chornyi Oleksii Petrovych. Tel. 067-5417900. E-mail: alekseii.chornyi@gmail.com Kremenchuk Mykhailo Ostrohradskyi National University,

vul. Pershotravneva, 20, Kremenchug, Poltava Region, Ukraine, 39600.

Відповідальний автор: Чорний Олексій Петрович. Тел. +380675417900. E-mail: ochornyi@ukr.net Кременчуцький національний університет імені Михайла Остроградського, вул. Першотравнева, 20, Кременчук Полтавської обл., Україна, 39600.
} 


\title{
Принципы визуальной оценки результатов тестирования с использованием эмоциональной составляющей
}

\author{
Юдина А. Л., Черный А. П., Сергиенко С. А. \\ Кременчугский национальный университет имени Михаила Остроградского, Кременчуг, Украина
}

\begin{abstract}
Аннотация. Показано, что альтернативой традиционной количественной оценке результатов тестирования является оценка с помощью визуального изображения лица, поскольку сочетание современных технологий обучения с методами визуального и эмоционального воздействия может обеспечить большую эфффективность по сравнению с традиционными, классическими методами. В работе обоснована возможность использования техники лиц Чернова в оценке и способы построения оценки - «лицо студента» по значениям многомерного вектора результатов тестирования, что позволяет провести оценку на интуитивном уровне. Представлены способы построения индивидуальных оценок каждого студента и интегрированных оценок студенческой группы на основе результатов прохождения тестов первого уровня. Приведены принципы и средства сопоставление ответов на вопросы теста с чертами лица и возможность их отображение в виде графических примитивов. Сформулированы основные положения технологии построения визуальной оценки результатов тестирования с использованием эмоциональной составляющей. Приведен пример построения визуальной оценки студентов с использованием техники лиц Чернова на основе статистической таблицы данных результатов тестирования.
\end{abstract}

Ключевые слова: интеллектуальная визуализация, лицо Чернова, способы оценки, оценка - смайлик.

\section{Bcmyn}

Навчальний процес у вищих закладах освіти - це система організаційних і дидактичних заходів, спрямованих на реалізацію змісту освіти на певному освітньо-кваліфікаційному рівні, відповідно до державних стандартів освіти. Він охоплює всі компоненти навчання: учасників навчального процесу, засоби, фрорми і методи навчання [1].

Одним з основних елементів оцінки якості освіти $€$ контроль знань та оцінювання навчальних досягнень студентів. Із значним збільшенням годин на самостійну роботу, завдання педагога зводиться не стільки до читання лекцій і проведення практичних і лабораторних занять, скільки до організації роботи студентів, створення методичного забезпечення навчального процесу і систематичного контролю за самостійною роботою студентів Поряд з традиційними методами контролю (іспити, заліки, колоквіуми), які не втрачають свого значення і не можуть бути виключені, сучасні технології навчання приділяють велику увагу контролю знань у вигляді тестів. Розробка методики створення, перевірки та оцінювання тестів поступово перетворюється в окремий напрямок наукових досліджень[2,3].

Метою даної роботи $€$ синтез методів побудови візуальних оцінок результатів виконання тестових завдань та розробка відповідних алгоритмів на основі сучасних когнітивних методів інтелектуальної візуалізації.

\section{II Матеріал і методи дослідження}

Поєднання сучасних технологій навчання з методами візуального і емоційного впливу може забезпечити більшу ефективність у порівнянні з традиційними, класичними методами. Поряд 3

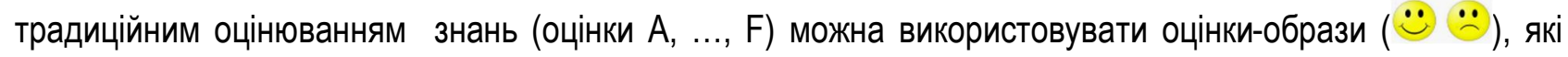
здійснюють значно більший емоційний вплив на студента.

Одним 3 найбільш відомих когнітивних методів інтелектуальної візуалізації багатовимірних статистичних даних, який можна використовувати для візуального оцінювання результатів виконання тестових завдань $€$ метод "обличь Чернова" [7], який, на відміну від традиційних графіків та діаграм, дозволяє співставити значення багатовимірного набору цифрових даних з людським обличчям та інтуїтивно виявити існуючи вади, якщо вони присутні.

Обличчя Чернова (Chernoff Faces) - це схема візуального представлення мультиваріативних даних у вигляді людського обличчя. Кожна частина особи: ніс, очі, рот - являє собою значення певної змінної, призначеної для цієї частини обличчя, всього до 18 змінних, а з урахуванням можливої ассиметрию - 36. 
Основна ідея методу полягає в тому, що люди легко розпізнають обличчя та без складнощів сприймають невеликі зміни в ньому. Концепція використання такої можливості сприйняття обличчя для побудови піктографіків була сфрормована американським математиком Германом Черновим.

Для відображення багатовимірних даних використовуються риси: розмір очей, розмір зіниці, позиція зіниці, нахил очей, горизонтальна позиція очей, вертикальна позиція очей, вигин брови, щільність брови, горизонтальна позиція брови, вертикальна позиція брови, верхня межа волосся, нижня межа волосся, контур обличчя; колір волосся, густина волосся, форма носу, розмір рота, вигин рота тощо.

В найпростішому випадку кожне обличчя може бути представлено масивом з $\mathrm{n}$ елементів, кожен з яких приймає значення від 0 до 1. За кожних елементом закріплено окрему частину обличчя. Параметри досліджуваних об'єктів приводяться до цих значень, відповідно екстремуми реальних приведених даних прийматимуть значення 0 і 1. За отриманим масивом приведених параметрів конструюється обличчя. Дана методика може бути використана як для відображення стану динамічних об'єктів в процесі моніторингу, так і для оцінювання статичних багатовимірних даних.

Для використання техніки обличчів Чернова в оцінюванні тестів можна побудувати «обличчя студента» за значеннями багатовимірного вектору оцінок тестів.

Складність застосування техніки Чернова полягає в правильному зіставленні досліджуваних змінних з частинами обличчя особи. При помилці важливі закономірності можуть залишитися непоміченими.

У зв'язку з цим, в контексті візуалізації результатів тестування важливі не тільки способи представлення результатів, а й методи їх структурування та інтегрування.

Традиційно кожен тест першого рівня складності представлений питанням і варіантами відповіді. Вибір правильної відповіді оцінюється в один бал, інакше бал не нараховується.

Робоча відомість, що містить результати тестування, представлена на рис. 1., і містить оцінки 3 кожного тестового питання (стовпці) по кожному студенту групи (рядки).

\begin{tabular}{|c|c|c|c|c|c|c|c|c|c|c|c|c|c|c|c|c|}
\hline 1 & Дата 4.12.2013 & & & & & & & & & & & & & & & \\
\hline 2 & ח..Б. & 1 & 2 & 3 & 4 & 5 & 15 & 16 & 17 & 18 & 19 & 20 & 21 & 22 & 23 & 24 \\
\hline 3 & Бейтул A.I. & 1 & 0 & 0 & 0 & 0 & 0 & 1 & 0 & 0 & 0 & 1 & 0 & 0 & 0 & 1 \\
\hline 4 & Войтко А.В. & 0 & 0 & 0 & 0 & 0 & 0 & 1 & 1 & 0 & 1 & 0 & 1 & 1 & 1 & 0 \\
\hline 5 & Гйка О.В. & 0 & 1 & 0 & 1 & 0 & 0 & 0 & 0 & 0 & 1 & 1 & 0 & 1 & 1 & 0 \\
\hline 6 & Запара B.Ю. & 0 & 0 & 0 & 0 & 0 & 0 & 1 & 0 & 1 & 1 & 0 & 1 & 1 & 1 & 0 \\
\hline 7 & Гончаренко О.Г. & 0 & 0 & 0 & 0 & 0 & 1 & 0 & 0 & 1 & 0 & 1 & 0 & 0 & 0 & 0 \\
\hline 8 & Друзенко Е.В. & 1 & 1 & 0 & 1 & 0 & 0 & 1 & 1 & 1 & 0 & 1 & 0 & 1 & 1 & 0 \\
\hline 9 & Ліман М.Ю. & 0 & 1 & 0 & 0 & 0 & 1 & 0 & 1 & 1 & 0 & 1 & 0 & 1 & 1 & 0 \\
\hline 10 & ЛЕжик А.В. & 1 & 0 & 0 & 0 & 0 & 1 & 0 & 1 & 0 & 0 & 1 & 0 & 1 & 0 & 0 \\
\hline 11 & Марченко A.C. & 0 & 0 & 0 & 1 & 0 & 0 & 0 & 0 & 0 & 0 & 0 & 0 & 0 & 1 & 0 \\
\hline 12 & Омелян I.O. & 0 & 0 & 0 & 1 & 0 & 1 & 1 & 0 & 1 & 1 & 1 & 0 & 1 & 0 & 0 \\
\hline 13 & Promir B.A. & 1 & 0 & 0 & 0 & 0 & 0 & 1 & 1 & 1 & 0 & 1 & 0 & 0 & 1 & 0 \\
\hline 14 & Пішеко B.I. & 0 & 0 & 0 & 1 & 0 & 1 & 0 & 1 & 1 & 0 & 0 & 0 & 1 & 0 & 0 \\
\hline 15 & Феськов Б.С. & 0 & 0 & 0 & 1 & 0 & 0 & 1 & 0 & 1 & 0 & 0 & 1 & 0 & 0 & 0 \\
\hline 16 & ЧГСКов M.A. & 1 & 1 & 0 & 0 & 0 & 0 & 0 & 0 & 0 & 0 & 0 & 0 & 1 & 1 & 0 \\
\hline 17 & Щербака М.M. & 1 & 0 & 0 & 1 & 0 & 1 & 0 & 0 & 1 & 0 & 0 & 0 & 0 & 1 & 0 \\
\hline
\end{tabular}

Рис. 1. Відомість з результатами тестування

Представлені дані можуть бути використані для отримання трьох різних оцінок тестування:

Перший тип. Оцінка по кожному студенту і кожному тесту окремо. У разі правильної відповіді на всі питання в якості оцінки буде побудовано ідеальне (еталонне) обличчя з кількістю ознак, що дорівнює кількості тестових питань. Кожна неправильна відповідь (оцінка «0» в таблиці) призведе до максимального спотворення саме тієї риси обличчя, за якою закріплене дане питання тесту. У разі поганої відповіді студента обличчя буде спотворено. 
Даний спосіб дозволяє отримати індивідуальну оцінку роботи кожного студента. Побудова набору таких «осіб» по різних датах проведення тестування дозволить оцінити динаміку зміни індивідуальних знань студента

Другий тип. Середня оцінка групи з кожного тестового питання. Обчислення середньої по всій групі оцінки за кожне тестове питання (рис. 2) дозволяє розрахувати вектор нормованих середніх оцінок, розмірність якого дорівнює кількості тестів.

Оскільки, як і в попередньому випадку, за кожним тестовим питанням закріплена окрема риса особи, ідеальному (еталонному) зображенню буде відповідати 100\% правильних відповідей всієї групи. Зменшення середньої оцінки в бік нуля з конкретного питання (колонки) буде викликати більше спотворення відповідної риси обличчя. Дана оцінка є інтегрованою і показує результати навчання всієї групи в цілому по кожній конкретній темі.

Третій тип. Оцінка групи по середній оцінці кожного студента. Обчислення середнього балу по кожному студенту (рис. 2) дозволяє розрахувати вектор нормованих середніх оцінок кожного студента, розмірність якого дорівнює кількості студентів в групі. На відміну від попередніх випадків, окрема риса особи закріплена за кожним студентом, але ідеального (Еталон) зображенню, як і раніше, буде відповідати 100\% правильних відповідей всієї групи.

\begin{tabular}{|c|c|c|c|c|c|c|c|c|c|c|c|c|c|c|c|c|c|c|}
\hline 1 & Дата 4.12.2013 & & & & & & & & & & & & & & & & & \\
\hline 2 & ПЈБ. & 1 & 2 & 3 & 4 & 5 & 15 & 16 & 17 & 18 & 19 & 20 & 21 & 22 & 23 & 24 & Сума батів & $\begin{array}{l}\text { Середнє } \\
\text { по } \\
\text { студенту }\end{array}$ \\
\hline 31 & Бейгул A.I. & 1 & 0 & 0 & 0 & 0 & 0 & 1 & 0 & 0 & 0 & 1 & 0 & 0 & 0 & 1 & 7 & 0,291667 \\
\hline 4 & Войтко A.B. & 0 & 0 & 0 & 0 & 0 & 0 & 1 & 1 & 0 & 1 & 0 & 1 & 1 & 1 & 0 & 12 & 0,5 \\
\hline 5 & Гиนка О.В. & 0 & 1 & 0 & 1 & 0 & 0 & 0 & 0 & 0 & 1 & 1 & 0 & 1 & 1 & 0 & 10 & 0,416667 \\
\hline 6 & Запара B.Ю. & 0 & 0 & 0 & 0 & 0 & 0 & 1 & 0 & 1 & 1 & 0 & 1 & 1 & 1 & 0 & 7 & 0,291667 \\
\hline 7 & Гончаренко О.Г. & 0 & 0 & 0 & 0 & 0 & 1 & 0 & 0 & 1 & 0 & 1 & 0 & 0 & 0 & 0 & 7 & 0,291667 \\
\hline 8 & Друзенко Є.В. & 1 & 1 & 0 & 1 & 0 & 0 & 1 & 1 & 1 & 0 & 1 & 0 & 1 & 1 & 0 & 11 & 0,458333 \\
\hline 9 & Ліман М.Ю. & 0 & 1 & 0 & 0 & 0 & 1 & 0 & 1 & 1 & 0 & 1 & 0 & 1 & 1 & 0 & 11 & 0,458333 \\
\hline 10 & ЛЕхаx А.B. & 1 & 0 & 0 & 0 & 0 & 1 & 0 & 1 & 0 & 0 & 1 & 0 & 1 & 0 & 0 & 9 & 0,375 \\
\hline 11 & Марченго A.C. & 0 & 0 & 0 & 1 & 0 & 0 & 0 & 0 & 0 & 0 & 0 & 0 & 0 & 1 & 0 & 5 & 0,208333 \\
\hline 12 & OMergir I.O. & 0 & 0 & 0 & 1 & 0 & 1 & 1 & 0 & 1 & 1 & 1 & 0 & 1 & 0 & 0 & 9 & 0,375 \\
\hline 13 & Promir B.A. & 1 & 0 & 0 & 0 & 0 & 0 & 1 & 1 & 1 & 0 & 1 & 0 & 0 & 1 & 0 & 11 & 0,458333 \\
\hline 14 & Піпкко B.I. & 0 & 0 & 0 & 1 & 0 & 1 & 0 & 1 & 1 & 0 & 0 & 0 & 1 & 0 & 0 & 8 & 0,333333 \\
\hline 15 & Феськов Б.C. & 0 & 0 & 0 & 1 & 0 & 0 & 1 & 0 & 1 & 0 & 0 & 1 & 0 & 0 & 0 & 10 & 0,416667 \\
\hline 16 & Чижов M.A. & 1 & 1 & 0 & 0 & 0 & 0 & 0 & 0 & 0 & 0 & 0 & 0 & 1 & 1 & 0 & 6 & 0,25 \\
\hline 17 & Щербака М.M. & 1 & 0 & 0 & 1 & 0 & 1 & 0 & 0 & 1 & 0 & 0 & 0 & 0 & 1 & 0 & 6 & 0,25 \\
\hline 18 & $\begin{array}{l}\text { Середнє по } \\
\text { групі }\end{array}$ & 0,40 & 0,27 & 0,00 & 0,47 & 0,00 & 0,40 & 0,47 & 0,40 & 0,60 & 0,27 & 0,53 & 0,20 & 0,60 & 0,60 & 0,07 & & \\
\hline 19 & & & & & & & & & & & & & & & & & & \\
\hline
\end{tabular}

Рис. 2. Відомість з середніми показниками за кожне питання і по кожному студенту

Зменшення середньої оцінки в бік нуля по конкретному студенту (рядку) буде викликати більше спотворення за відповідною межах особи. Дана оцінка так само є інтегрованою і показує результати навчання всієї групи з відображенням середніх результатів кожного студента.

\section{III Результати}

Для реалізації технології візуалізації оцінок тестування створено програмний додаток, головною функцією якого $є$ побудова обличчя з набору графічних примітивів. Вхідною інформацією $є$ дані таблиці результатів тестування, що зберігаються у вигляді xls-файлів. Дані упорядковані по групах студентів і по датах проведення тестів.

Технологію формування оцінки-зображення першого типу представимо на простому прикладі. Нехай тестується група з восьми студентів, результати тестування представлені в таблиці (рис. 3).

Згідно наведених даних, студент Іваненко отримав по одному балу за кожну відповідь i, відповідно, має отримати максимальну оцінку. Відомо, що питання в таблиці відповідей впорядковані за 
ступенем їх важливості, тому найважливішим питанням поставимо у відповідність найважливіші риси обличчя - очі, брови, рот, тощо. Тоді за результатами відповідей на перші три питання згідно наведеної таблиці відповідей, оцінки студентів Іваненко, Петренко, Павленко будуть відповідати «смайлики», представлений на рисунку 4, а, б, в відповідно.

Для відображення результатів тестування з інших питань застосовано протилежний підхід: якщо відповідь $€$ невірною, і студент отримав нуль балів, на обличчі з'являються додаткові риси, які збільшують сумарну негативну емоційну складову сприйняття обличчя. Це можуть бути додаткові зморшки на лобі, між бровами, тощо.

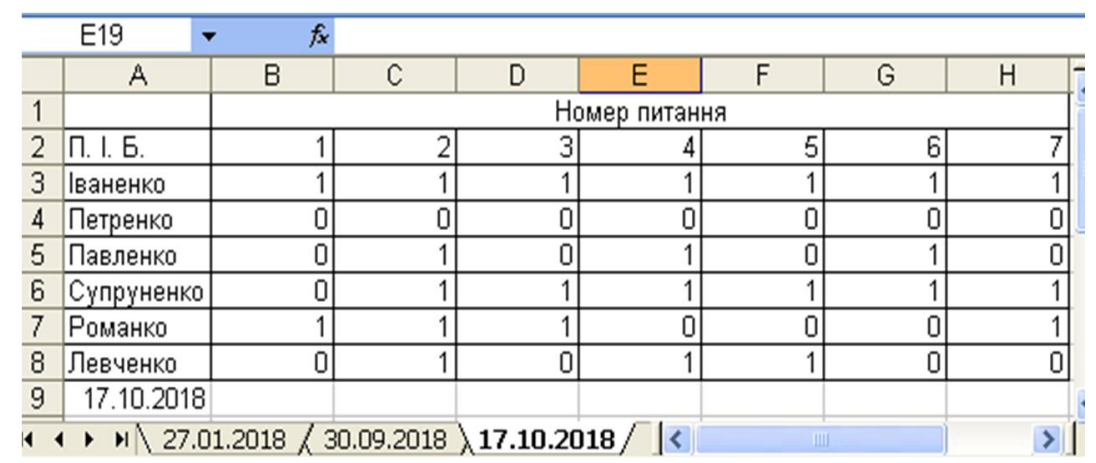

Рис. 3. Результати тестування у вигляді xls-файлів.

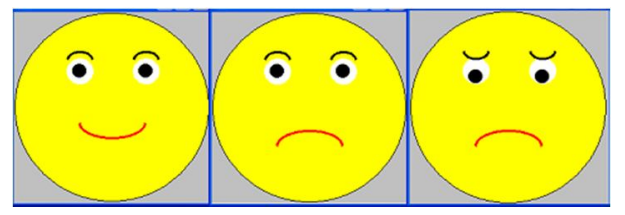

Рис. 4. Оцінки студентів за три перші питання тесту

3 урахуванням усіх відповідей студентів Петренко і Павленко, їх оцінка - смайлик представлена на рисунку 3 а, б відповідно. Оцінка студента Іваненка залишається такою ж, як показано на рисунку 2,а, оскільки він дав правильні відповіді на всі тести і його результат $є$ найбільшим кількісно - 7 балів і найвеселішим візуально.

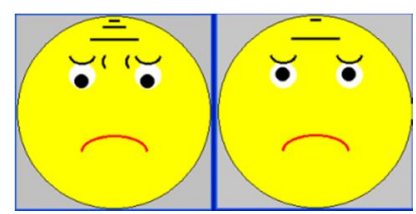

Рис. 5. Оцінки студентів за повний набір тестових питань

Наведені приклади дозволяють сформулювати положення техніки побудови візуальної оцінки результатів тестування:

- зображення формується з використанням техніки обличь Чернова;

- зображення оцінки містить емоційну складову;

- питання тесту мають бути впорядковані за ступенем їх важливості та значимості;

- кожному питанню тесту має відповідати окрема риса обличчя.

\section{IV Обговорення}

За результатами наукового аналізу сучасного стану розвитку інтелектуальних інформаційних технологій, дослідники виділяють[4] технології символьного типу (тобто, раціоналістичні за своєю природою та принципами обробки символьної інформації) і технології візуалізації, де базовою компонентою і механізмом дії є принцип образної обробки інформації. Причому, якщо перший різновид - інформаційно-символьні системи - на сучасному етапі набувають достатньо широкого рівня 
розвитку та розповсюдження і в повній мірі домінують; то другий різновид — візуалізація (інформаційнообразні структури) - лише набирають потужності і знаходяться на початковому етапі свого розвитку.

3 іншого боку, сучасна теорія освіти приділяє велику увагу емоційній складовій навчання.. Емоціогенні фрактори $є$ своєрідним двигуном спілкування і впливу. 3 метою переконання студента викладач звертається до його емоцій і почуттів, створюючи психологічне підґрунтя для ефективного сприймання інформації. На думку Г. К. Ліхтенберга, навіть найглибша думка, навіть найзмістовніша інформація, яка не пробуджує емоцій людини, залишає її байдужою, перетворитися в пере- конання не може [5, с. 214]. Ще у 30-ті роки XX ст. психолог П. П. Блонський науково довів, що найкраще пам'ять зберігає інформацію, емоційно значущу. Інфрормація, до якої людина не відчуває ніяких почуттів, зберігається в її пам'яті недовго [6, с. 183].

Аналіз інформаційних повідомлень користувачів соціальних мереж дозволяє зробити висновок, що найбільш вживаною піктограмою з емоційним вмістом $€$ «смайлик» $[8,9]$, тому саме на базі цього зображення було вирішено використати техніку обличь Чернова.

\section{V Висновки}

Сучасні тенденції розвитку системи освіти вимагають впровадження новітніх методів ведення та оцінювання знань. Представлені в даній роботі принципи побудови системи оцінювання 3 використанням сучасних інтуїтивно зрозумілих зображень, які містить емоційну складову, дозволяють збільшити ефективність впливу на студентів та мотивувати їх для покращення результатів оцінювання. Даний підхід вимагає подальшого розвитку і вдосконалення, проведення додаткових досліджень, оскільки застосовані методи формування зображення мають обмеження по кількості елементів тестів і не враховують можливості зміни геометричного положення риси обличчя і можливостей їх асиметричного застосування.

\section{Бібліографічні посилання}

[1] Національна доктрина розвитку освіти [Електронний ресуpc]. URL: http://www.mon.gov.ua (дата звернення 02.03.2019).

[2] СмолінчукЛ. С. Тестування як метод оцінювання навчальних досягнень студентів. URL: http://jrnl.nau.edu.ua/index.php/VisnikPP/article/viewFile/2146/2137 (дата звернення 02.03.2019).

[3] Красильникова В. А. Теория и технологии компьютерного обучения и тестирования : монография. Москва : Дом педагогики, ИПК ГОУ ОГУ, 2009. 339 с.

[4] Кожем'яко В. П., Яровий А. М., Яровий А.А. Візуалізація як унікальна інформаційно-інтелектуальна технологія: потреба нової методології та нового логічного базису / Оптико-електронні інфоормаційно-енергетичні технології. 2014. №2(28). С. 5-16.

[5] Лихтенберг Г. К. Афоризмы. М. : Наука, 1965. 344 с.

[6] Шаховский В. И. Эмотивный компонент значения и методы его описания : учебное пособие к спецкурсу. Волгоград : ВГПИ, 1983. 94 с.

[7] Chernoff H. "The Use of Faces to Represent Points in K-Dimensional Space Graphically». Journal of the American Statistical Association 68 (342), 1973, C. 361-368.

[8] Суховей Е. Семь научно обоснованных причин использовать смайлы в социальных медиа. URL: https://pgenerator.ru/blog/2015/04/20/sem-nauchno-obosnovannyh-prichin-ispolzovat-smajly-v-socialnyh-media/ (дата звернення 02.03.2019).

[9] Маковецька-Гудзь Ю. А. Українська мова в соціальних мережах. URL: http://philology.knu.ua/ files/library/ movni_i_konceptualni/47-1/77.pdf (дата звернення 02.03.2019).

\section{References}

[1] Natsional'na doktrȳna rozvȳtku osvitȳ. Retrieved from: http://www.mon.gov.ua

[2] Smolinchuk, L. S. (2012). Testuvannya yak metod otsinyuvannya navchal'nȳkh dosyahnen' studentiv. Visnȳk Natsional'noho aviatsiinnoho universȳtetu. Seriya: Pedahohika, Psȳkholohiya, 1(3), 74.

[3] Krasilnikova, V. (2017). Teoriya i tekhnologii kompyuternogo obucheniya i testirovaniya. Litres.

[4] Kozhem"yako, V. P., YArovȳĭ, A. M., \& YArovȳ̄̆, A. A. (2014). Vizualizatsiya yak unikal'na informatsiinno-intelektual'na tekhnolohiya: potreba novoyi metodolohiyi ta novoho lohichnoho bazȳsu. Optȳko-elektronni informatsiïno-enerhetȳchni tekhnolohiyi, 28(2), 5-16.

[5] Likhtenberg, G. K. (1965). Aforizmy. Moskva: Nauka.

[6] Shakhovsky, V. I. (1983). Emotivny komponent znacheniya i metody ego opisaniya : uchebnoye posobiye k spetskursu. Volgograd : VGPI 
[7] Chernoff, H. (1973). The use of faces to represent points in k-dimensional space graphically. Journal of the American Statistical Association, 68(342), 361-368.

[8] Sukhovey, Ye. (2015). Sem nauchno obosnovannykh prichin ispolzovat smayly v sotsialnykh media. Retrieved from: https://pgenerator.ru/blog/2015/04/20/sem-nauchno-obosnovannyh-prichin-ispolzovat-smajly-v-socialnyh-media/

[9] Makovets'ka-Hudz, Yu. A. (2013). Ukrayins'ka mova v sotsial'nȳkh merezhakh. URL: http://philology.knu.ua/files/library/movni_i_konceptualni/47-1/77.pdf (accesed 02.03.2019).

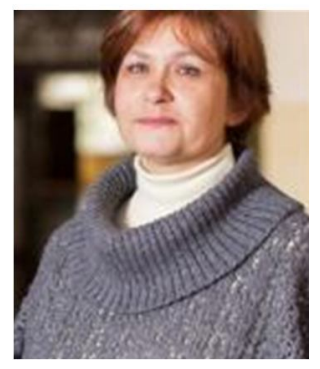

\section{Юдіна Анна Леонідівна.}

Старший викладач, кафедра Комп'ютерних і інформаційних систем, Кременчуцький національний університет імені Михайла Остроградського, вул. Першотравнева, 20, Кременчук Полтавської обл., Україна, 39600. Тел. +380987041318. E-mail: iyusa@ukr.net

\section{Yudina Anna Leonidivna.}

Senior Lecturer, department "Computer and Information Systems", Kremenchuk Mykhailo Ostohradskyi National University, vul. Pershotravneva, 20, Kremenchug, Poltava Region, Ukraine, 39600.

Tel. +380987041318. E-mail: iyusa@ukr.net

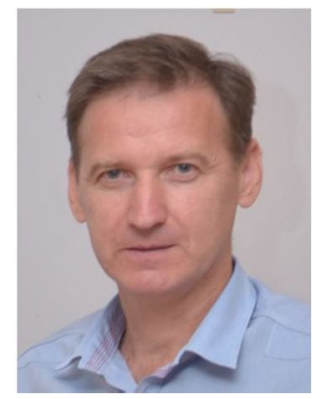

\section{Чорний Олексій Петрович.}

Д.т.н., профессор, директор Інституту електромеханіки, енергозбереження і систем управління, Кременчуцький національний університет імені Михайла Остроградського, вул. Першотравнева, 20, Кременчук Полтавської обл., Україна, 39600.

Тел. +380675417900. E-mail: ochornyi@ukr.net

\section{Chornyi Oleksii Petrovych.}

Doctor of Technical Sciences, Professor, Director Institute of Electromechanics, Energy Saving and Automatic Control Systems of Kremenchuk Mykhailo Ostrohradskyi National University,

vul. Pershotravneva, 20, Kremenchug, Poltava Region, Ukraine, 39600.

Tel. 067-5417900. E-mail: alekseii.chornyi@gmail.com
ORCID: 0000-0001-8270-3284
Researcher ID: P-3527-2018
Scopus ID: 57039206300

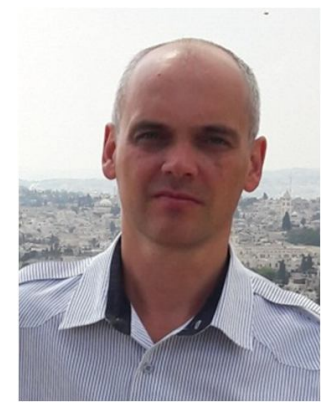

\section{Сергієнко Сергій Анатолійович.}

К.Т.н., проректор Кременчуцького національного університету імені Михайла Остроградського, вул. Першотравнева, 20, Кременчук Полтавської обл., Україна, 39600.

Тел. 098-4334771. E-mail: serhiy.serhiyenko@gmail.com

\section{Serhiienko Serhii Anatoliiovych.}

Candidate of Technical Sciences, Associate Professor, Pro-rector

of Kremenchuk Mykhailo Ostrohradskyi National University

vul. Pershotravneva, 20, Kremenchug, Poltava Region, Ukraine, 39600.

Tel. 098-4334771. E-mail: serhiy.serhiyenko@gmail.com

ORCID: 0000-0002-3977-5239

Researcher ID: 0-6912-2018

Scopus ID: 57196471214

\section{Citation (APA):}

Yudina, A., Chornyi, O., Serhiienko, S. (2019). Principles of visual evaluation of test results using the emotional component. Engineering and Educational Technologies, 7 (2), 98-104. doi: https://doi.org/10.30929/2307-9770.2019.07.02.10

\section{Цитування (ДСТУ 8302:2015):}

Юдіна А. Л., Чорний О. П., Сергієнко С. А. Принципи візуальної оцінки результатів тестування з використанням емоційної складової / Інженерні та освітні технології. 2019. Т. 7. № 2. С. 98-104. doi: https://doi.org/10.30929/2307-9770.2019.07.02.10

Обсяг статmі: сторінок - 7 ; умовних друк. аркушів - 1,014. 